Oxford and in Germany led him by way of NeoKantism to an idealist position akin to that of Bradley, and thence to the ria media on which he took a firm stand during the last twenty years of his life, and to which he gave the appropriate name of 'C'ritical Realism'. The problems that most engaged his mind were in the fields of theory of knowledge and the philosophy of religion. His realism, evidenced in the refusal to allow any "bifurcation of Nature", was, in many respects, akin to that of Whitehead. Why, he kept asking, should not the grass be really green ? $\mathrm{He}$ contended resolutely against the naturalistic fallacy of treating the knowing subject as an object among other objects. Perhaps his most characteristic doctrine was the threefold distinction that he discerned, alike in perceptual and conceptual thinking, between the activity of apprehension, the content apprehended, and the apprehended object; a distinction by which he endeavoured, in a manner reminiscent of the scholastic distinction of the $i d$ quod concipitur (the object) from the id quo concipitur (the concept), to escape both the Scylla of naïve realism and the Charybdis of representative perception.

In religion Hicks was all his life a member of the Unitarian communion, in which he had in earlier years exercised the ministry, from 1897 until 1903, at Unity Church, Islington. In his Hibbert Lectures he set himself to expound the rational grounds for his strong theistic faith. The strength of the book lies in its massive presentation of the cosmological, teleological, and moral arguments as a correlated sequence of evidence to a God, who is at once distinguishable from the Absolute of monistic idealism and subject, on epistemological grounds to temporal succession. The weakness lies in the author's evident lack of sympathy with any form of mysticism and in his disparagement of the evidence from religious experience. The thought of man's relation to God as that of a subject to a subject seems scarcely to have crossed his mind.

That Hicks left no finished system of philosophy was doubtless due in part to his lack of speculative imagination. He cannot be ranked with thinkers like Bradley, Alexander or Dr. Whitehead. But he threw much light - a dry light, as befits a philosopher -on many of the most important problems of modern thought. In early days, for example, he had studied psychology and psycho-physics under Wundt, Heinze, Volkelt and Hering, an interest that was fortified and deepened later through his friendship with James Ward. A striking essay on "The Dynamic Aspect of Nature" and another in criticism of Sir Arthur Eddington testify to his grasp of recent developments in physics. He gradually came to be recognized as one of the most competent and judicious thinkers of his generation; his old University of Manchester conferred on him a doctorate, and in 1927 he was elected a fellow of the British Academy. $\mathrm{He}$ will be long remembered with honour as a great scholar and teacher, a disinterested inquirer after speculative truth, and one of the most lovable of men.

W. G. DE Burgh.

\section{Prof. C. R. Lanman}

WE regret to record the death of Prof. C. R. Lanman, the distinguished authority on the ancient languages and culture of India, emeritus professor of Sanskrit in Harvard University, which took place at Boston on February 20 at the age of ninety.

Charles Rockwell Lanman was born at Norwich, Connecticut, on July 8, 1850. He graduated at Yale in 1871 and was awarded his Ph.D. in 1873 for his studies in Greek and Sanskrit. Further studies of Sanskrit and comparative philology followed during a period of four years spent at Berlin and Tübingen, where he was a student under the most distinguished authorities in these subjects of the day, among them Roth and Curtius. During 1876-80 he held an appointment as lecturer on Sanskrit at Johns Hopkins University, Baltimore, and was then elected to the chair of Sanskrit in Harvard University, which he occupied for fifty-six years. During his tenure, in 1889, he travelled extensively in India with the object of securing books in his subject for the library of his University. His tour was highly successful, the accessions he acquired numbering some thousand items including both books and manuscripts. In 1890 he delivered the Percy Trumbull Lectures at Johns Hopkins, his subject being Indian poetry, and lectured at the Lowell Institute, Boston, on Indian literature and early history.

Lanman was a fellow of the American Academy of Arts and Sciences and edited the Transactions of the American Philological Association, of which he was secretary and in 1890 president. He also edited the publications of the American Oriental Society for some years, serving successively as its corresponding secretary, vice-president and president, holding the latter office on two occasions, in 1907 and 1919.

In addition to his editorial activities, Lanman himself published a number of works on Sanskrit, including "Hindu Drama" (1900) and "The Beginnings of Hindu Pantheism" (1890). He was also responsible, in association with the leading Orientalists of the whole world, for the Harvard Oriental series, of which forty volumes have been published, containing editions of most of the classics of the ancient East. Among the numerous honours he received in recognition of his eminence in Oriental studies, was a gold medal on the occasion of the celebration in Japan of the 2,500th anniversary of the birth of the Buddha. He was a corresponding member of the British Academy.

WE regret to announce the following deaths:

Dr. C. R. M. F. Cruttwell, principal of Hertford College, Oxford, during 1930-39, on March 14, aged fifty-three.

Mr. J. P. Gilmour, editor of the Pharmaceutical Journal during 1916-33, on March 10, aged eighty.

Dr. E. L. Ince, lecturer in technical mathematics, University of Edinburgh, on March 16, aged fortynine.

Prof. Mary S. Rose, professor of nutrition in Teachers College, Columbia University, on February 1, aged sixty-six. 